\title{
A poesia de Yeda Prates Bernis
}

\author{
Ângela Vaz Leão*
}

\begin{abstract}
RESUMO
$\mathrm{O}$ artigo pretende realizar uma leitura sucinta da poesia de Yeda Prates Bernis, publicada em onze livros, no período de mais ou menos quatro decénios, entre 1976 e 2013. A metodologia adotada não tem nenhuma relação com as atuais correntes críticas da Teoria da Literatura. Inspirase apenas na tradicional explicação de textos de origem francesa, sem se esquecer do obrigatório recurso a numerosas citações literárias extraídas dos textos em análise.

Palavras-chave: Yeda Prates Bernis. Explicação de textos. Citações literárias.
\end{abstract}

A leitura de Entressombras (2013), a mais nova publicação de poemas de Yeda Prates Bernis, despertou em mim, além da costumeira admiração pela beleza de seus versos, o desejo de reler, ainda uma vez, os seus textos mais antigos. E foi o que fiz: dei um mergulho fundo na profunda poesia de Yeda. Fui percorrendo os dez volumes que precederam Entressombras, na ordem de sua publicação. $\mathrm{E}$ aí me veio a vontade de escrever um artigo que desse aos possíveis leitores não familiarizados com a poesia de Yeda uma ideia, ainda que superficial, do conjunto de sua obra. Queria que fosse um artigo cheio de citações de poemas, isto é, um artigo em que a bela voz poética de Yeda ocupasse tanto espaço quanto a minha própria voz prosaica. Isso, porque a maioria das suas publicações, a não ser a última, deve achar-se esgotada. E o meu propósito seria despertar naqueles possíveis leitores amantes de poesia um certo gosto, ou pelo menos uma certa curiosidade em torno da obra dessa grande Poetisa mineira. Como fazê-lo, senão multiplicando as citações de seus poemas, sem lhes poupar espaço? Pois foi assim que fiz.

O primeiro livro de Yeda Prates Bernis, Entre o rosa e o azul, de 1967, vem ilustrado por quatro belos desenhos a bico de pena da saudosa Sara Ávila e apresentado por prefácio de Mário Matos e posfácio de Martins de Oliveira. Fazem ambos o prognóstico da fulgurante carreira poética de Yeda.

Nos poemas dessa primeira coletânea, a voz de Yeda se ouve inteira, sem

* Professora Emérita da Universidade Federal de Minas Gerais - UFMG - e professora Titular da Pontifícia Universidade Católica de Minas Gerais - PUC Minas. 
implícitos, em textos às vezes quase narrativos, embora já cortados, de longe em longe, por momentos de expressivo silêncio. Os versos são livres, mas isso não impede a existência de algumas composições de medida regular. No poema "Saudade", que transcrevo abaixo, cada estrofe, do ponto de vista versificatório, é um dístico em redondilha maior, enquanto, do ponto de vista sintático-semântico, é um conjunto de definições da saudade em frases completas, porém com elipse do verbo principal. Leiamos o poema:

\section{Saudade}

Saudade, flor de ternura que nasce dentro da gente.

Saudade, lágrima quente que rola dentro da gente.

Saudade, canto tristonho que canta dentro da gente.

Saudade, balé de sombras que dançam dentro da gente.

Saudade, flor de ternura que morre dentro da gente.

(BERNIS, 1967, p. 65).

As únicas concessões ao convencionalismo da versificação parecem ser o uso da redondilha maior e a rima ou, melhor, a reiteração do mesmo sintagma "dentro da gente", nos segundos versos dos cinco dísticos. No mais, "Saudade" é um poema moderno em vários aspectos. Note-se, por exemplo, o jogo de oposições entre a primeira e a última estrofes. Sua redação seria idêntica, se não fosse quebrada pelo contraste semântico entre os verbos "nascer" na primeira e "morrer" na última estrofe:

\footnotetext{
Saudade, flor de ternura que nasce dentro da gente.

(...)

Saudade, flor de ternura que morre dentro da gente.
}

Observe-se, também, em todos os dísticos, a reiteração anafórica da palavra "Saudade" e o coloquialismo do vocabulário, fatores certos da beleza do poema. 
Pelos temas tratados, o volume Entre o rosa e o azul se divide em três subconjuntos de poemas, intitulados "Temas de mãe", "Temas vários", "Temas de amor". No primeiro deles, seis belos poemas cantam a maternidade, desde a espera até o embalo do filho que nasceu. No segundo, a temática se multiplica: é a poesia que chega, com o vento do outono, com os primeiros cabelos brancos e a premonição de um futuro ignoto. Já no terceiro e último subconjunto, o tema que reina, soberano, é o amor. O destinatário é sempre o mesmo, invocado na segunda pessoa do discurso, como num diálogo em que não se espera resposta. Os poemas são belos exemplares de poesia amorosa, dentre os quais se destaca o metapoema "Oferenda":

\section{Oferenda}

Se eu pudesse fazer um poema meigo como a brisa das manhãs, doce como pássaro submisso, lírico como a flor que desabrocha,

se eu pudesse fazer um poema onde as palavras perdessem seu sentido e se transformassem em etéreas formas em música suave ou em volátil perfume que inebriasse,

levar-te-ia, amor, em oferenda, este mágico poema.

(BERNIS, 1967, p. 95).

"Oferenda" não é apenas um belo exemplar de poema de amor. E também um belo exemplar de poesia autorreferencial, ou, lembrando Jacobson e suas funções da linguagem, é um metapoema: um poema que fala de si próprio, "este mágico poema", e que é idealmente descrito por quem faz a oferenda.

Sete anos depois, em 1974, vem à luz o segundo livro de Yeda, Enquanto é noite, prefaciado por Henriqueta Lisboa. São vinte poemas, também em versos e estrofes irregulares, de métrica pouco convencional, como fora o primeiro livro. Porém, naquele primeiro volume publicado, o conjunto de trinta e cinco poemas se estruturava, como vimos, em apenas três subconjuntos de temas. Já neste segundo, o conjunto de vinte poemas forma uma sucessão de grande diversidade temática. 
Ainda assim, em meio à variação dos temas e das formas, algumas composições se distinguem pela busca de certa regularidade estrutural. Veja-se, por exemplo, este fragmento de poema:

\section{Fragilidade}

Tênue concha
indefesa
sob pés
desavisados.
Pomba voando
inocente,
atirador
à espreita.
Delicada
flor de estufa
sob sol
canicular.
(...)

(BERNIS, 1974, p. 43).

Nos dois primeiros versos dessas três estrofes iniciais, temos seres femininos "concha indefesa..., pomba voando..., flor delicada" - ameaçados, na sua fragilidade, pela violência dos seres masculinos dos dois últimos versos de cada estrofe - "pés desavisados..., atirador à espreita..., sol canicular".

O poeta de tais versos só poderia ser, sem nenhum desdouro, uma poetisa. Aliás, chamá-la de "a poeta, uma boa poeta", como se tem feito ultimamente, em vez de "a poetisa, uma boa poetisa", segundo a velha tradição do português, sempre me pareceu um sinal de preconceito: preconceito às avessas, mas preconceito... Yeda Prates Bernis, assim como Henriqueta Lisboa, Cecília Meireles ou Gabriela Mistral, para citar apenas algumas, são grandes poetisas. Mas, só são poetisas porque são poetas, é claro! Ou será que, para ser verdadeiro poeta torna-se necessário renunciar ao feminino? E por que essa restrição de gênero não ocorre na nomenclatura de outras profissões? Convido os leitores a examinar duas frases, possíveis no português de hoje:

$\rightarrow$ Entre os escritores que conheci, não houve nenhuma poeta.

$\rightarrow$ Entre os religiosos que conheci, não houve nenhuma sacerdote.

Brincadeiras à parte, que achar desses novos femininos? Não ficaria melhor dizer "nenhuma poetisa" e "nenhuma sacerdotisa"? Continuo, pois, a dizer que Henriqueta, Gabriela, Cecília e Yeda são grandes poetisas. Um preconceito não pode valer mais do que a gramática de uma língua. 
Mas deixemos esse desabafo, talvez extemporâneo, e voltemos ao segundo livro de Yeda. A dor sem revolta, o cantar na ausência, a espera e a desesperança, toda uma gama enfim de sentimentos, sugeridos desde os títulos, se deixam entrever ao longo dos poemas de Enquanto é noite. A essa variedade temática responde a grande diversidade formal, quer na medida dos versos, quer no contorno das estrofes, quer nos constituintes da frase. Com efeito, esses constituintes ora são explícitos até a quase redundância, ora implícitos como num jogo de adivinhações. No poema "Bem-aventurança", por exemplo, em que todos os versos dos seis dísticos são formados por sintagmas nominais, não há um verbo sequer.

Bem-aventurança

Não a estrela mais brilhante mas o simples vagalume.

Não a pedra mais preciosa mas o seixo pequenino.

Não a orgulhosa orquídea mas a modesta violeta.

Não o pensamento sábio mas o puro, de criança.

Não a força do comando mas a força da humildade.

Não a coroa de ouro, mas a mais tosca, de espinhos

(BERNIS, 1974, p. 91).

De um verso para o outro, a conjunção adversativa "mas" contrasta, de um lado, a plenitude, a opulência, o orgulho, com, de outro, a pequenez, a modéstia, a simplicidade. Porém, a ausência do verbo torna obscura a relação entre os dois grupos de seres contrastados. Estaria essa relação suficieníemente clara para a Poetisa? Isto é: seriam rejeitados por ela os seres do primeiro grupo, enquanto de sua preferência os do segundo? Ou outra hipótese: o ocultamento do verbo, com certeza intencional, visaria a preservar a multivocidade da linguagem poética e, em consequência, a liberdade de interpretação do leitor? Impossível saber ao certo.

A terceira coleção de poemas de Yeda publica-se em 1979, sob o título Palavra ferida. Como a primeira publicação da Poetisa, esta também vem ilustrada por 
Sara Ávila, agora em magníficas aquarelas, inspiradas no belo rosto da Autora dos poemas. Prefácio de Alphonsus de Guimarães Filho e orelhas de Edgar da Mata Machado conferem ao livro o seu merecido aval.

A diversidade estrutural dos poemas, que veio crescendo desde o primeiro livro, torna-se ainda maior neste terceiro, revestindo-se também de grande originalidade. Encontram-se poemas de forma totalmente inusitada, como "Árvore", em que a Autora toma a árvore por destinatária, num vocativo inicial. Depois, dirige-se a ela em cada estrofe, iniciada por um verbo no infinitivo, que se destaca à esquerda e começa sempre pela vogal "a" - adivinhar-te, auscultar-te, abraçar-te, amar-te - em expressiva gradação semântica, indo do "adivinhar-te" ao "amar-te". A esse artifício versificatório soma-se o uso da aliteração em cada uma das três estrofes: o poema se encerra por um último infinitivo verbal solitário, que o sintetiza em explícita declaração de amor à árvore:

\section{Árvore}

Adivinhar-te,

pressentir

por teus

poros a

palpitação de

pássaro

prisioneiro.

Auscultar-te,

rumor de

rio calmo em

ramos e

raízes

- remanso,

refrigério.

Abraçar-te,

sorver em

silêncio o

segredo de tua

sensível e

serena

seiva.

Amar-te.

(BERNIS, 1979, p. 11). 
Essa estrofação original nem sempre tem caráter obrigatório: o estro inovador de Yeda não é incompatível com a tradição da quadra, que se faz presente em alguns poemas, em versos brancos. Porém, a adesão a essa estrofe tradicional (e até popular) libera a força poética de Yeda para concentrar-se na ideia: "o que morre no sonho" (...) é esta "luz se desmanchando em sombras", esta "sombra se esgarçando em nadas". Leiamos o poema inteiro:

\section{Do sonho}

O que escorre, do sonho, é este líquen de fascínio e mistério, seiva de cactos, sumo de transcendentes pétalas.

O que vive, no sonho, é este frêmito de asas peregrinas, esta música sutil descortinando auroras.

O que morre, no sonho, é esta flor deixada no deserto, esta luz se desmanchando em sombras, esta sombra se esgarçando em nadas.

(BERNIS, 1979, p. 49).

Uma originalidade estrutural logo chama a atenção neste livro. É uma espécie de epígrafe geral, estranha a princípio e válida para todo o conjunto: "Vocacional estrabismo divergente / um olho na terra". Assim iniciada na página da esquerda, na abertura do livro, antes do primeiro poema, que vem na página da direita, aquilo que parecia uma epígrafe geral, vai se repetindo ao longo do livro, sempre na página da esquerda, porém com o acréscimo, a cada página, de meio, um, ou dois versos. A pretensa epígrafe vai sendo transformada, assim, pouco a pouco, num longo poema de grande beleza. É o autorretrato de Yeda:

\section{Autorretrato}

Vocacional estrabismo divergente: um olho na terra, outro no céu. Nadadora, vai singrando em largas ou tímidas braçadas oceanos, rios e lagos de emoção. Solfeja alguns idiomas para ler poemas, 


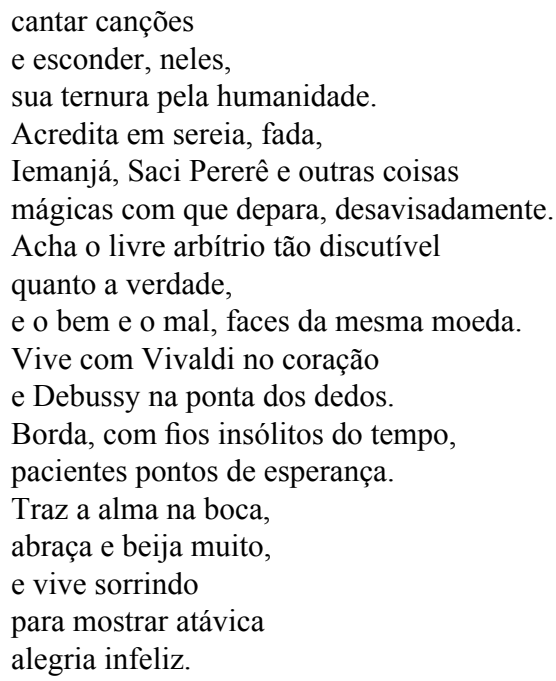

(BERNIS, 1979, p. 91).

Autorretrato tão fiel como esse só poderia resultar de autoexame muito lúcido. Embora o poema seja escrito na terceira pessoa, é o "eu" da Poetisa que aí se retrata. Com efeito, Yeda aí está, inteira, com seu canto emocionado, sua leitura poliglota, sua ternura por todos os seres, suas crenças ingénuas, sua coragem de discutir verdades feitas, seu amor à música e sua fala transparente, que lhe revela a alma. Ao final, o retrato todo, às vezes contraditório, se resume numa "alegria infeliz", verdadeiro oximoro psíquico, se assim se pode dizer, onde sentimentos opostos de uma alma inquieta buscam seu ponto de harmonia. Encontrarão um dia esse ponto? Que importa? Vale a beleza do poema.

Pêndula é o quarto livro de Yeda, publicado em 1983, com inteligente leitura de Audemaro Taranto Goulart, estampada nas duas orelhas. As páginas não são numeradas, e uma epígrafe tirada do "Eclesiastes" abre a coleção de poemas:

Para tudo há um tempo.

Para cada coisa há um momento debaixo dos céus.

(Eclesiastes, 3:1).

E depois desse tempo bíblico, marcado para todas as coisas, vêm os tempos de Yeda, marcadores de sua poesia. Assim, dão ensejo a poemas que se estruturam 
em tempos diversos, adequados a cada hora do viver, como quer o "Eclesiastes".

Minúsculo e admirável poema, por exemplo, "Violência", apenas com quatro versos dissilábicos, oito sílabas métricas portanto, nos faz tremer de horror diante da incomensurável ameaça da tecnologia moderna:

\title{
Violência
}

Um míssil

explode

o rosto

de Deus.

(BERNIS, 1983, p. 21).

Crente ou descrente, ninguém fica insensível ao poema "Violência", essa sugestão de fím de mundo que Yeda insere em "Tempo para matar", uma das partes de Pêndula.

No extremo oposto, vem o "Tempo para guardar", que anuncia o mais longo poema do livro. São nove estrofes desiguais, que evocam as diferentes "Vozes de Minas", já passadas. E de quem são essas vozes? Sem declinar o seu dono, Yeda trata de evocá-las. A genial voz barroca que cinzelou o grito dos profetas; a voz pura do mártir ainda a acordar o futuro; a voz mariana do poeta; a fabulosa voz das veredas e sertões; a filosófica voz emiliana; a seresteira porém ciclópica voz juscelina; a sábia e justa voz miltoniana: onde estão essas vozes de Minas? Leiamos a última estrofe do longo poema:

\author{
Vozes de Minas, \\ ganga sonora \\ arcaz de grave \\ lastro do eterno. \\ Vozes de Minas \\ onde estais? \\ Nos quintais, \\ no coração \\ dos pardais. \\ nos beirais, \\ nos ais \\ do nunca mais.
}

(BERNIS, 1983, p. 53).

A melancólica beleza da estrofe final lembra ao leitor que aqueles seres de elite - cantados anonimamente nas outras estrofes, - mas que o leitor logo identifica na sequência como sendo o Aleijadinho, Tiradentes, Cláudio Manuel da Costa, 
Guimarães Rosa, Emílio Moura, Juscelino Kubitscheck e Milton Campos fizeram a história de Minas. E suas vozes, num final melancólico, repercutem "nos ais / do nunca mais". Final melancólico, sim - nos ais / do nunca mais - porque a história não se repete, e "nunca mais" Minas terá seres de elite como esses que fizeram a sua história.

Em Grão de arroz (1986), a pena de Yeda registra, dócil, a voz de Yeda, que, nesse quinto livro, só canta haicais. Oswaldino Marques, em elogioso prefácio, dá esclarecimentos sobre a natureza dessa espécie poética:

O haicai é a forma mais sucinta da poesia japonesa. (...) Consiste de três versos, o primeiro e o último de cinco sílabas e o intermédio de sete. (...) Em que pese à sua brevidade, o haicai é um poema completo em si mesmo. Em seu exíguo espaço, pode projetar uma paisagem ou a subjetividade (p. 13) (...) Posto que Yeda Bernis observe o cânone estético, é livre a estruturação prosódica (MARQUES apud BERNIS, 1986, p. 16).

O haicai de Yeda é feito à custa de imagens, metáforas, elipses e todas as figuras mais, de que se vale a poesia. Também composto de três versos, não obedece, entretanto, à métrica do haicai tradicional. Foi certamente sua originalidade que levou Oswaldino Marques a denominá-lo "haicayeda".

Não é fácil, na safra dos "haicayedas", todos belos, escolher quais os mais belos. Faço uma opção: escolho apenas alguns deles, dando preferência àqueles que têm como tema a água ou os animais:

\section{Na poça dágua \\ o gato lambe \\ a gota de lua.}

(BERNIS, 1984, p. 33).

Neblina sobre o rio, poeira de água sobre água.

(BERNIS, 1984, p. 41).

Cai da folha a gota dágua. Lá longe o oceano aguarda.

(BERNIS, 1984, p. 89). 
Pássaros em silêncio.

Noturna chave

tranca o dia.

(BERNIS, 1984, p. 43).

Inútil. A gaiola

nunca aprisiona

as penas do canto.

(BERNIS, 1984, p. 57).

Ângelus. Dedos da brisa

nas teclas das folhas

adormecem os pássaros.

(BERNIS, 1984, p. 77).

Essa pequena amostra de haicais à maneira de Yeda dá uma pálida ideia da riqueza do livro Grão de arroz, título bem achado pela sua adequação: por um lado, a diminuta dimensão do grão de arroz casa bem com a reduzida dimensão do haicai; por outro lado, a cultura do arroz, típica dos povos orientais, nos remete à cultura do haicai como fruto de particular sensibilidade poética, também oriental.

Chega 1992 e Yeda publica o seu sexto livro, O rosto do silêncio, com prefácio de Lacyr Schettino. São 28 poemas, diversificados pela temática, porém reveladores de algumas constantes da poesia de Yeda.

À primeira leitura, nota-se a contenção estilística, já presente em livros anteriores. O poema "Alquimia”, que com cinco versos abre o livro, é tão conciso que, à custa de algum esforço, poderia comprimir-se em um haicai. Pouco faltaria para isso:

Alquimia

Enterrei meu canarinho junto à roseira.

Agora, a primeira rosa

vai amanhecer

cantando.

(BERNIS, 1992, p. 11).

Com perdão da ousadia, façamos a experiência do haicai:

Canarinho enterrado

junto à roseira. Nasce cantando

a primeira rosa. 
Prosseguindo a leitura, em alguns poemas reaparece uma religiosidade difusa, já presente em outros momentos da obra. É quando, em "Teofania”, entre galáxias e labirintos, "o rosto de Deus sonha acordado as coisas e seus nomes". (BERNIS, 1992, p. 38).

Mas essa impressão distante e diáfana se toma próxima e concreta, quando, em Kioto, um monge medita num jardim, enquanto toda a natureza também se cala em oração. E Yeda tem a certeza de que Deus está ali. Ouçamos a voz, quase prece, da Poetisa:

Junto a um templo

Tardinha.

Jardim em Kioto.

O tempo dormia nas coisas.

A um canto um monge

zentranquilo, sorriso de nuvem,

meditava.

Pedras oravam silêncios,

Flores celebravam lago e lótus.

$\mathrm{O}$ lago, quase céu.

$\mathrm{O}$ lótus, quase lua.

Deus estava lá, descansando.

(BERNIS, 1992, p. 27).

Belo poema! O neologismo "zentranquilo", aplicado ao monge que medita, sintetiza a parada do tempo, a dormência das coisas, a oração silenciosa das pedras, a presença de Deus em descanso.

Mas há um traço especial que distingue $O$ rosto do silêncio de todos os outros livros: é a demonstração do amor da Autora pela língua de Racine e Baudelaire. O poema "Chanson pour Guilherme de Figueiredo" [Canção para Guilherme de Figueiredo], em alexandrinos rimados de impecável expressão francesa, traz um agradecimento de Yeda ao poeta e amigo, pela beleza de seus versos a Jean Sablon. As palavras de Guilherme de Figueiredo levam Yeda a recuar até a infância e a reencontrar, através de Sablon, o rio Sena e o ar de Paris. Cito pequenas passagens do original francês, cuja tradução faço em seguida, entre colchetes, em atenção aos leitores que, por desconhecimento dessa língua, poderiam, talvez, perder a beleza dos versos de Yeda:

Merci, mon ami, pour la beauté de tes vers sur Sablon (...)

Je te dois mon enfance éclairée, mon ami,

et ma mémoire des temps qui jamais ne reviennent. 


\section{(...) Je retrouve, sans cesse, à travers Jean Sablon un reflet de soleil, comme un fil de chanson que je déroule lentement de mon passé (...) Ah! merci, mon poète, pour me rendre la Seine, des fleurs, l'air de Paris, tant de rêves (...)}

(BERNIS, 1992, p. 40).

[Obrigada, meu amigo, pela beleza de teus versos sobre Sablon (...) Eu te devo, meu amigo, minha infância iluminada e minha lembrança dos tempos que não voltam mais. (...) Através de Jean Sablon, eu reencontro, sem cessar, um reflexo de sol, como o fio de uma canção que eu desenrolo lentamente de meu passado (...) Ah! obrigada, meu poeta, por me devolveres o Sena, as flores, o ar de Paris, tantos sonhos (...).]

Mas não é só aí que Yeda atesta seu amor à língua francesa. Ainda outra vez, em $\mathbf{O}$ rosto do silêncio, nos versos de "Migração", a Autora se dirige a um pássaro, que ela vai buscar num poema de Jacques Prévert, poema "impregnado de sortilégios". Pelas minhas lembranças de antiga professora de francês, o poema de Prévert só pode ser "Pour faire le portrait d'un oiseau" [Para pintar o retrato de um pássaro]. Nem o Poeta francês nem a Poetisa brasileira, nenhum deles declina o nome do pássaro. Para Yeda, entretanto, essa ausência de nomenclatura não tem importância; antes, é adequada ao desenrolar do poema:

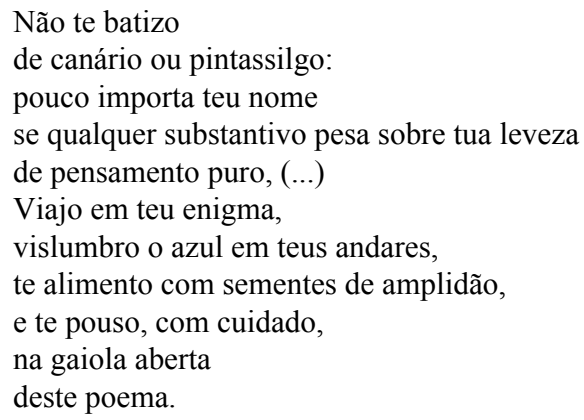

(BERNIS, 1992, p. 37).

O poema de Prévert começa pela pintura de uma gaiola e a espera paciente e silenciosa da entrada do pássaro. E fínalmente ele entra. Fechada a porta com o pincel, o pintor desmancha, uma a uma, todas as finas grades em torno da gaiola, tendo o cuidado de não tocar o pássaro com o pincel. Pinta depois uma árvore com a folhagem verde que recebe a frescura do vento. Escolhe o mais belo dos galhos. Aí pendura a gaiola e espera que o pássaro se decida a cantar. Se ele cantar, diz 
o Poeta/Pintor, é bom sinal: terminada a pintura, o pintor já poderá assinar o seu nome num cantinho do quadro.

Assim, no poema de Prévert, o pássaro é preso e só depois libertado da gaiola, então aberta, ou melhor, desmanchada, pouco a pouco, na pintura do quadro. Já nos versos de Yeda, o pássaro jamais foi preso. Ao contrário. Nutrido "com sementes de amplidão", ele é depositado na gaiola já aberta que é o próprio poema.

Em ambos, pois, o pássaro está "em liberdade". Impossível ler esse poema de Yeda com a sua tácita alusão a Prévert sem lembrar dois outros grandes poetas que cantaram "a liberdade": Paul Éluard e Henriqueta Lisboa, por coincidência também um francês e uma brasileira, igualmente cultuados pela nossa Poetisa.

Henriqueta, celebrando o crescimento da cidade, em "Belo Horizonte bemquerer" - ruas que se traçam, casas que se erguem, palácio que se constrói -, celebra também o crescimento, no espírito dos mineiros, do "senso de liberdade", estrela-guia da história de Minas, desde a morte de Felipe dos Santos no Brasil colônia até os dias de hoje. Já Eluard constrói longo poema em discurso direto, "Hymne à la liberté" [Hino à liberdade], evocando as inúmeras situações em que ele, desde a infância até a maturidade, por toda a parte, escrevia essa palavra. Também no poema, continua a repeti-la, como se fosse um refrão: J'ecris ton nom: LIBERTÉ [Eu escrevo o teu nome: LIBERDADE]. (ÉLUARD, 1968).

Em 1994, vem à luz o sétimo livro de Yeda, À beira do outono. Três dezenas de poemas curtos se sucedem, longe de atingir a extensão de uma décima. Alguns têm os versos em distribuição estrófica, outros se alinham em sequência corrida. À beira do outono constitui o conjunto mais homogéneo publicado pela Autora. Nele comparecem alguns traços estilísticos presentes em outras obras suas, como a economia verbal. Leia-se, por exemplo, o poema "Dúvida", onde a concisão quase tende ao silêncio:

\section{Dúvida}

O que tocou de leve na pele de meu desejo foi um floco de neve ou foi teu beijo?

(BERNIS, 1994, p. 60).

Também o poema "Quase haicai” resulta dessa palavra contida:

Quase haicai

Do beiral dos dias cai sobre mim tênue chuva de estrelas, 
estou molhada de luz.

(BERNIS, 1994, p. 52).

Outra característica da poesia de Yeda em À beira do outono, é mais complexa, porquanto tríplice: ela associa a composição poética em tercetos ao tratamento do tema da natureza e à presença da música, quando não nos poemas, pelo menos no seu título. Nessa linha temática, leiamos "Variações em tom maior", em que o tema da noite vai-se diluindo no da madrugada, enquanto, em tom maior, o sino desperta flores e pássaros:

\section{Variações em tom maior}

A noite, trémula, com seu fardo de sombras nos ombros.

Ponteiros invisíveis giram, esgarçam, pouco a pouco, um fado de opaca tristeza.

Um galo, voz claríssima, chameja em prata espaço entre as trevas.

Borboletas brincam de roda: sobre um sino, acordam o silêncio de bronze.

Uma azaleia molhada de cristal ensaia voo.

Asas de andorinhas salpicam no céu claridades e levezas.

(BERNIS, 1994, p. 13).

"Variações em tom maior" é o mais longo poema do livro À beira do outono. Nele, enquanto a noite, pouco a pouco, vai se diluindo na madrugada, a natureza animal e vegetal se anima, em consonância com a música de um sino que, em tom maior, desperta o silêncio. 
Segue-se Encostada na paisagem, de 1998, onde poemas de variadas composições alternam com novos haicais, no mesmo estilo dos "haicayedas" de Grão de arroz. Leiamos alguns deles:

\author{
Vem o beija-flor \\ do horizonte \\ molhado de arco-íris.
}

(BERNIS, 1998, p. 11).

Neblina.

Papel de seda embrulha

a paisagem.

(BERNIS, 1998, p. 39).

O estrume do boi

a seiva do lírio:

alquimia.

(BERNIS, 1998, p. 57).

Não retire

de seus olhos

este fiapo de sol.

(BERNIS, 1998, p. 17).

Prece em silêncio,

verde inocência:

louva-deus.

(BERNIS, 1998, p. 29).

A água do lago:

pranto dos chorões

que moram ao lado?

(BERNIS, 1998, p. 13).

Coerentemente, o livro se fecha por um poema que é uma curiosa receita poética para se compor um haicai:

Receita para um haicai

Se você quer compor um haicai, à moda de Bashô, mesmo imperfeito, verifique primeiro se já viveu inúmeras vidas.

Comece por despojar-se do supérfluo

das vestes da alma:

paletó de esnobismo, 
camisas de inquietude, agasalhos de orgulho, meias de apegos.

Deixe o espírito, em síntese, aquietar-se, desnudo.

Perceba o cintilar da essência de tudo que o rodeia,

Veja o mundo com o olhar dos anjos.

Faça de seus ouvidos concha de inocência, imite o Poeta Francisco.

(BERNIS, 1998, p. 79).

Aos que aspiram a ser poetas, Yeda deixa aí sábios conselhos, inspirados em dois de seus mestres: o Poeta Franscisco, que na sua Assis do século XIII, cantou o irmão Sol e a irmã Lua, e o Poeta Bashô, que, lá no seu Japão do século XVII, ensinou aos discípulos como fazer haicais. Com ambos ela aprendeu a despojar-se da matéria e a desnudar a alma, condições para captar a essência das coisas.

Em 2004, Yeda Prates Bernis publica Cantata, com o subtítulo "Antologia poética / Não cronológica". Os poemas da antologia foram selecionados, a pedido da Autora, por seus amigos e também poetas Márcio Sampaio e Bartolomeu Campos de Queirós. A este último deve-se também o prefácio, que apresenta o livro como uma parte significativa do trajeto literário de Yeda. O título, Cantata, é de origem italiana e designa uma forma musical, composição de conteúdo lírico, relativamente extensa, em que as vozes têm acompanhamento instrumental. Os poemas, nesse livro, se reagrupam em subconjuntos que também recebem títulos em italiano, igualmente designativos de andamentos musicais - "Andante" (p. 2937), “Tempo giusto" (p. 39-62), “Allegro" (p. 63-83), "Dolce” (p. 87-113).

Fiel ao meu propósito de proporcionar aos leitores o conhecimento (ou reconhecimento) de textos de Yeda Prates Bernis, hoje quase só possível em bibliotecas por estarem esgotados os livros, citarei alguns poemas, tirados de três dos subconjuntos citados.

Do primeiro subconjunto, "Andante", destaco "Francisco", nome do poeta e santo que Yeda já havia celebrado em "Receita para um haicai", citado acima. Vejamos o belo poema de agora, que, em discurso direto, canta as virtudes do santo de Assis: 
Francisco

Teu gesto, sagrada

vitória

da loucura.

Teus passos, pegadas

de luz

pelos tempos.

Teu espírito,

leveza

de voo

de teus pássaros.

Teu amor, reflexo do olhar

divino.

(BERNIS, 2004, p. 36).

No subconjunto "Dolce", vários poemas têm por título o nome de um instrumento musical, como "A flauta" (p. 88), "Solo de oboé" (p. 95), "Violoncelo" (p. 106). Outros falam do canto, o que não nos deixa esquecer a exímia musicista e cantora que é Yeda. Vejamos:

\section{Improviso}

Dom maior é canto

de arcanjos - semibreve.

No princípio, um jubilato

arrebata aleluias.

Pouco e pouco, a escala

se despeja em decrescendo

de afiados bemóis

e rasga os dias.

Até que o solo de um clarim

- antes novelo de lã,

fio de aço agora -

estrangula o amanhã.

(BERNIS, 2004, p. 89). 
O último subconjunto de poemas, o maior de todos, é "Pianíssimo", que se compõe somente de haicais, forma poética por mais de uma vez cultivada por Yeda. Citemos apenas dois deles que, como muitos outros, falam de animais:

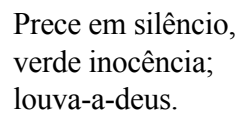

(BERNIS, 2004, p. 165).

O coração da aranha

se desfaz em geometria

de seda e mandala

(BERNIS, 2004, p. 172).

Após a numerosa série de belos haicais, o livro Cantata se fecha por uma riquíssima fortuna crítica da obra de Yeda, com nada menos que quatorze páginas, iniciadas por Antônio Cândido de Mello e Souza e encerradas por Oswaldino Marques. Seria necessário alguma coisa mais para atestar a qualidade dessa poesia?

Passemos ao livro seguinte, Viandante, de 2006, que Yeda oferece a seu marido, Ney Octaviano Bernis. Havia pouco, empreendera ele sua última viagem, aquela viagem definitiva que todo homem fará um dia, sem comprar passagem e sem sequer conhecer a data da partida.

Ney partira, deixando Yeda sem o companheiro que escolhera para a vida inteira. Mas daquela cumplicidade amorosa que tiveram, restava-lhe a poesia. Com ela Yeda comporia para Ney um volume de grande beleza, não só pelos poemas sentidos a ecoar saudade, mas também pelos dramáticos recortes de fotos em branco e preto que os acompanham.

Os poemas são curtos: na maioria, dísticos em discurso direto. O cúmulo da brevidade ocorre, porém, em poemas de um só verso, como este:

Teu perfume no travesseiro beija meu rosto molhado.

(BERNIS, 2006, p.85).

Molhado de quê? É preciso dizê-lo? Assim, com poucas palavras, em mistura com alguns silêncios e muitos implícitos, Yeda vai tentando reatar o diálogo que a "indesejada das gentes" viera interromper.

Para isso, busca consolo na lembrança de coisas que Ney amou - o queijo mineiro, a camisa do América, as massas italianas, o canarinho que deixou de cantar, os óculos que a espiam de sobre a mesa de trabalho. 
E verdade: os óculos ainda a espiam. Mas será que ainda a vêem? Impossível saber. Yeda, porém, continua ainda a ver o amado:

Meus olhos te perderam.

E como te vejo!

(BERNIS, 2006, p. 31).

Ela o vê como se vivo ele estivesse. Palavras como "morte" e outras do mesmo campo semântico nunca aparecem nos poemas. E como se o gentil "viandante", cavalheiro como sempre, tivesse partido um pouco antes de sua dama apenas para preparar-lhe o caminho e espera-la à chegada.

Porém até que venha esse tempo do reencontro, Yeda continuará a evocar aquela vida-a-dois, sem revoltar-se pela separação forçada. Ao contrário, Yeda a aceita e até procura acalentar a tristeza que ela lhe traz.

No silêncio manso deste poente, de minhas mãos faço berço para minar a tristeza.

(BERNIS, 2006, p. 29).

Enquanto isso, vai ouvindo a mensagem de uma voz ausente:

A ausência de tua voz é mensagem que recebo de momentos indizíveis. (BERNIS, 2006, p. 69).

Mas um dia virá - dia sem marca - em que também Yeda será "viandante". Então, atravessará o mistério, levando para o amado um doce aroma de rosas:

Não esperaste pelo nascer das rosas, tão adivinhadas.

Vou-te levar o perfume delas.

(BERNIS, 2006, p. 23).

E ambos esperam: ela, pela hora da partida; ele, pela chegada dela. Ambos, pelo reencontro.

Passam-se sete anos. E em 2013, Yeda Prates Bernis publica o seu undécimo livro de poemas, Entressombras, com apresentação - "Uma palavra" - de Maria Lúcia Simões e prefácio - "O simbolismo imaginário da água e do tempo" - de Lina Tâmega Peixoto.

A estrutura do livro traz, como sempre, algo de novo em relação aos anteriores. Neste, cerca de uma trintena de poemas, impressos nas páginas da direita, 
relacionam-se com sentenças que, nas páginas da esquerda, funcionam como espécies de epígrafes para os poemas. São frases que a autora tomou a pensadores dos mais diversos estilos e línguas. Máximas, definições poéticas, descrições de instantâneos da natureza, todas hauridas em filósofos e poetas os mais variados, de diferentes terras e épocas, assim como em poetas brasileiros do presente - eis a espécie de citações que, quase à guisa de temas explícitos, introduzem os poemas de Yeda. Sirva de exemplo esta definição do tempo, que Yeda busca em Platão:

O tempo é a imagem móvel da eternidade imóvel.

(BERNIS, 2013, p. 38).

Na página em frente, lê-se um poema de Yeda, que se inspira nessa concepção platoniana do tempo móvel, concretizada, aí, na célebre imagem do rio, de outro filósofo antigo, Heráclito de Êfeso. Leiamos o poema:

\section{O rio de Heráclito}

O rio de Heráclito
inexiste no mapa.
Atroz geografia
carrega em seu leito
tanto flor de laranjeira
como rastros de sangue
e corre em artérias
e seivas e nadas.
O rio de Heráclito
navega entre luzes
e sombras e ódios
e amores, impávido.
Inútil a barragem
de sonhos, coragem:
deságua nas águas
do eterno. Sem mágoas.

(BERNIS, 2013, p. 39).

Como se sabe, o rio de Heráclito, não é um acidente geográfico. É simplesmente um fato de linguagem, um ser mental a serviço de uma imagem - a imagem do tempo. Logo, conforme se lê no poema, esse rio "inexiste no mapa". Mais do que isso: inexiste na natureza. A ideia do filósofo, entretanto, não é gratuita: repousa no fato de que ninguém se banha duas vezes no mesmo rio, já que as suas águas, como o tempo, fluem sem cessar. "Pánta réi", tudo flui, diz o grego. E, nesse fluir 
constante, o rio tudo carrega em seu curso - e nos carrega também — até que suas águas, em movimento, desagúem nas águas do eterno, essas sim, imóveis e sem limites.

Essa oposição entre o instante que passa e o eterno, entre a transitoriedade e a perenidade, acha-se tematizada em outros poemas de Entressombras. Leiamos, por exemplo:

\section{Fluvial}

Mítico relógio

não se importa com dezembro ou janeiro.

As horas

deslizam sem apelo

entre flores, pedras, sargaços.

O que foi, passou.

O que virá, incógnita.

Resta navegar nas águas deste Agora

até desaguar

na imensidão de um mar.

(BERNIS, 2013, p. 41).

"Pánta rei": tudo flui, tudo passa. Não só os poemas de Yeda expressam essa ideia da transitoriedade de tudo, mas também o fazem algumas das frases em prosa transcritas nas páginas da esquerda do livro e selecionadas por ela para introduzir seus poemas. Só que os poemas o fazem de forma imagética ou alegórica, transformando o "pánta réi" em poesia, enquanto aquelas frases citadas em prosa o fazem, muitas vezes, em linguagem direta, usando as palavras em sentido próprio, sem metáforas. Como fez Boileau, citado em português pela Poetisa:

Depressa o tempo foge e arrasta-nos consigo, o momento em que falo já está longe de mim.

(Nicole Boileau)(BERNIS, 2013, p. 28).

Bom exemplo, esse, também para quem quiser mostrar a diferença entre prosa e poesia. E só contrastar essa frase de Boileau com um dos poemas de Yeda sobre o tempo. Ficará patente a distância que há entre o prosaico e o poético.

Finalmente, encerro meus comentários sobre Entressombras pela leitura do poema "Sabedoria", que fecha a coletânea. Na página da esquerda, lê-se um verso 
de Henriqueta Lisboa, "Quero o silêncio perfeito", que dá o tema da composição, além de servir de epígrafe ao poema de Yeda, transcrito na página da direita:

\section{Sabedoria}

O sol a lua as estrelas
as montanhas as colinas
a orquídea a rosa a camélia
o jardim a gota d'água
- quietude zen -
aprenderam desde sempre
e rnais que os homens
a eloquência do silêncio

(BERNIS, 2013, p. 85).

A estruturação dos elementos constituintes do poema fazem dele um modelo de ordenação linguística, descendo do infinitamente grande - o sol, a lua, as estrelas ao infinitamente pequeno - a gota d'água. Verso a verso, temos, primeiro, os astros nos confins do universo, depois os acidentes da superfície da Terra, em seguida as flores do jardim, e por fim a gota d'água. Desde sempre, em calada meditação, vêm todos ensinando aos homens a eloquência do silêncio.

Também para mim vai chegando a hora do silêncio. Lamento que tanta coisa tenha ficado por dizer a respeito da obra poética de Yeda Prates Bernis, que é, sem dúvida, exponencial no panorama da poesia brasileira contemporânea.

Excluindo Cantata, que não é uma nova coleção de poemas, mas, sim, uma antologia em reedição da obra já publicada até aquele momento, Entressombras fica sendo a décima obra de Yeda Prates Bernis. Mas que não seja a última, espero eu. Faço votos para que outras ainda venham a público e tenham o êxito que tiveram as anteriores. As letras mineiras, ou melhor, brasileiras, só têm a ganhar com poesia desse quilate. Espero que a modesta leitura que fiz de alguns poemas de Yeda Prates Bernis possa contribuir para que um ou outro leitor, não satisfeito com as amostras aqui deixadas, mas motivado por elas, vá aos originais. Estará cumprido o meu propósito. Pois nenhuma amostra, seja cópia literal, seja mera paráfrase, substitui a palavra poética de Yeda.

\section{Résumé}

Cet article a pour but de faire une lecture résumée de la poésie d' Yeda Prates Bernis, publiée en onze volumes jusqu'à présent, dans une période de plus ou moins quatre décennies, de 1976 à 2013. La méthode adoptée n'a 
rien à voir avec les actuels courants critiques de la Théorie de la Littérature. Elle s'inspire simplement de la traditionnelle explication de textes d'origine française, sans oublier le recours obligatoire à de nombreuses citations litteraires, puisées dans les textes sounis à l'analyse.

Mots-clé: - Yeda Prates Bernis. Explication de textes. Citations textuelles.

\section{Referências}

BERNIS, Yeda Prates. Entre o rosa e o azul. Rio de Janeiro: Editora O Cruzeiro, 1967.

BERNIS, Yeda Prates. Enquanto é noite. Belo Horizonte, Imprensa Oficial, 1979.

BERNIS, Yeda Prates. Palavra ferida. Belo Horizont: Editora Veja, 1979.

BERNIS, Yeda Prates. Pêndula. São Paulo: Editora Massao Ohno, 1983.

BERNIS, Yeda Prates. Grão de arroz. Belo Horizonte: Editora Itatiaia, 1986.

BERNIS, Yeda Prates. O rosto do silêncio. Belo Horizonte: Editora Cuatiara, 1992.

BERNIS, Yeda Prates. À beira do outono. Belo Horizonte: Editora Phrasis, 1994. BERNIS, Yeda Prates. Encostada na paisagem. Belo Horizonte: Editora Phrasis, 1998.

BERNIS, Yeda Prates. Cantata. Edição da Autora, 2004.

BERNIS, Yeda Prates. Viandante. Edição da Autora, 2006.

BERNIS, Yeda Prates. Entressombras. Belo Horizonte: Rona Editora, 2013.

ÉLUARD, Paul. CEuvres Complètes. Paris: Éditions Gallimard, 1968.

Submetido em: 01 de dezembro de 2015.

Aceito para publicação em: 05 de dezembro de 2015. 
